\title{
The Impact of the Economic Downturn in the Spanish Civil Justice System
}

\author{
Laura Carballo Piñeiro \& Jordi Nieva Fenoll*
}

\begin{abstract}
The Spanish justice system has been shaken by the economic downturn as many other institutions have. This article addresses in the first place some statistical data that shed light as regards to the number of judges and the costs and length of the procedure in Spain. These figures help to understand, in the second place, the impact of austerity measures on the judiciary, namely, the freeze on the hiring of judges and the establishing of high court fees. While they mainly concern the supply side of justice services, others such cost reductions in legal aid have had, in the third place, an impact on the demand side, driving many citizens to social exclusion and to resorting to self-defence mechanisms. The final part of this article addresses some remedies that may alleviate judiciary's workload, but that fall short of doing it. All in all, the Spanish justice system seems to require a holistic approach to patch up edges, but one in which the role of judge-made justice in a democratic society has to be central again.
\end{abstract}

Keywords: judiciary, judge-made justice, court fees, legal aid, ADR-methods

\section{Introduction}

Spain has not only experienced the global economic downturn, but also a crisis on its own, mainly stemming from the malfunction of its housing market. The age of austerity is thus not a metaphor, but a reality when it comes to this country and to its justice system. The latter has experienced significant budget restrictions, but more importantly, its capability to solve social conflict has been put through a very hard test during these years, delivering intermingled results and a profound

\footnotetext{
Laura Carballo Piñeiro is Associate Professor of Private International Law at the Common Law Department of the University of Santiago de Compostela. Jordi Nieva Fenoll is Professor of Procedure Law at the Administrative and Procedure Law Department of the University of Barcelona. This article has benefited from comments from peer-reviewers, who the authors wish to thank; all opinions and errors are their own.
}

dissatisfaction on the citizen side, ${ }^{1}$ while the supply side of justice services shrank as a result of budget reductions, the demand side escalated as a consequence of the economic downturn as well as legal problems indirectly unveiled by it and that would have been better served by a legal and not a judicial solution. In short, the common understanding in Spain is that the judiciary is the ultimate guarantee of democracy, but its organisation and functioning are not in line with the needs of a modern society. ${ }^{2}$

This article does not seek to propose any reform, but to provide an account of the impact of the economic downturn in the Spanish civil justice system. To this end, the territorial organisation of Spain must be taken into account. Along with the Central State, the Comunidades Autónomas have also legislative and governmental powers, but not the judicial one as there is only one judiciary in the whole territory, governed by a General Council, the Consejo General del Poder Fudicial (hereafter, CGPJ). ${ }^{3}$ Hence, the budget of the justice system is mainly decided by the Spanish Parliament. However, some administrative competencies have been transferred to the Comunidades Autónomas such as the allocation of material resources to courts and the hiring of support staff save the case of court clerks who are deemed part of the judiciary and recruited by the Central Government. Furthermore, the European Union has also a role to play on account of the many Regulations and Directives dealing with access to justice and that are applicable in Spain; remarkably, the right to an efficient reme-

1. The degree of absolute dissatisfaction with the justice system has been constantly increasing since 2005 where $19.8 \%$ of participants in a barometer conducted by the Spanish Centre on Sociological Research (CIS - Centro de Investigaciones Sociológicas) answered that they were not satisfied with the system at all; in 2014 that percentage was $38.4 \%$. In contrast, those taking part in the same barometer and answering to be only a little bit satisfied with the justice system remain steady, from $39.4 \%$ in 2005 to $40 \%$ in 2014 . These figures have been gathered in a statistical publication entitled 'La percepción de los ciudadanos sobre la Administración de Justicia' (N.38, Diciembre 2014), available at <www. poderjudicial.es/cgpj/es/Temas/Estadistica-Judicial/Analisis-estadistico/ Datos-de-la-Justicia/La-percepcion-de-los-ciudadanos-sobre-laAdministracion-de-Justicia--N-38--Diciembre-2014->.

2. The Spanish Council of Bar Associations, or Consejo General de la Abogacía Española (hereafter, CGAE), has published on 8 July 2015 a barometer on lawyers' opinion, among others, on this issue, and $92 \%$ of participants agree that it is necessary to reach a State Pact to reform the justice system. See Figure 3.5 available at <www.abogacia.es/wpcontent/uploads/2012/05/INFORME-GENERAL-BAROMETROINTERNO-CGAE-JULIO-2015.pdf>.

3. In addition to the Spanish Constitution, the key law is that on the judicial power or Ley Orgánica 5/1985, de 5 de julio, del Poder Judicial (hereafter, LOPJ). 
dy before a tribunal is enshrined in Article 47 of the European Charter of Fundamental Rights. Be as it may be, the Spanish justice system provides relief in small and simple matters in the age of austerity, ${ }^{4}$ but a number of measures has been taken, or not been undertaken, that have clearly downgraded the system in the last years.

The justice system has never been a priority for most countries and Spain is not an exception. Nevertheless, many efforts have been made to improve the system in the last thirty years, in particular in terms of increasing judicial staff. Along with the political interest in appointing judges already educated in constitutional values, such an investment has been justified on the grounds of Spain falling largely behind other European countries in number of judges. ${ }^{5}$ In fact, these low figures seem to be endemic despite the said efforts as it is addressed in the second part of this article which aims to provide a picture of the civil justice system in terms not only of the number of judges, but also of the length and average costs of proceedings. Those figures seem to be necessary to properly assess the impact of budget restrictions in the justice system.

The third part of this article addresses the budget restrictions undertaken by the Government on the grounds of austerity, both with a clear impact on the judiciary's workload and thus on access to justice, i.e. the freeze in hiring judges and support staff, and the generalisation of high court fees. While this part of the article focuses on austerity in the justice administration, i.e. the supply side, the fourth part puts emphasis on the demand side and thus on the impact of austerity measures in citizens by dealing, first, with the fragile situation of legal aid in Spain and second with the resorting to self-defence mechanisms experienced in Spain in view of the lack of activism to solve crucial problems. The Spanish judiciary is not responsible of such reactions, yet they have unveiled that in the twenty-first century, courts cannot restrict themselves to be the mouth that pronounces the words of law, but they have to take on a more proactive role providing meaningful solutions to real problems.

The last part of this article is devoted to mechanisms that can give relief to an important number of citizens and, thus, discharge the justice system of many cases. In general, the Spanish civil procedure law system is well

4. On this concept see X. E. Kramer and S. Kakiuchi, 'Relief in Small and Simple Matters in an Age of Austerity', at 7 (25 May 2015), available at SSRN: <http://ssrn.com/abstract=2610773>. Small and simple matters is also an open concept in Spain, but one that can be fulfilled by making reference to verbal proceedings' scope of application. In addition to ordinary proceedings, the Spanish Civil Procedure Act, Ley 1/2000 de Enjuiciamiento Civil (hereafter LEC), provides for a simplified proceeding called procedimiento verbal in cases under 6,000 $€$ value and others expressly indicated by law and in particular in Art. 250 LEC on the grounds of requiring a prompt solution.

5. See The 2014 EU Justice Scoreboard. Communication from the Commission to the European Parliament, the Council, the European Central Bank, the European Economic and Social Committee and the Committee of the Regions [COM(2014) 155 final], Figure 27, available at <http://ec.europa.eu/justice/effective-justice/files/justice_scoreboard_ 2014_en.pdf>. provided of mechanisms which facilitate access to justice. Small and simple matters find their way into courts via simplified proceedings - in which legal assistance of a lawyer is not always compulsory - and others such as the order for payment procedure by summons or consumer collective actions. Consumer arbitration administered by the State has been made available for consumer matters as well. In fact, the Government has justified the aforementioned high court fees on the grounds of the alternative dispute resolution methods available for citizens. Nevertheless and without questioning the need for promoting such methods, policies seeking to discharge courts of cases are of secondary interest to the primary one, of granting citizens access to a judge-made justice. The point to be made is that hampering access to justice cannot be justified by the availability of ADR mechanisms, thereby forgetting that the State shall guarantee the aforementioned right of each citizen to an effective and timely judicial review.

\section{A Statistical Picture of the Spanish Civil Justice System}

\subsection{Length of Litigation and Average Number of Judges}

In line with the General Report for the XV World Congress of Procedural Law presented by Xandra Kramer and Shusuke Kakiuchi on Relief in Small and Simple Matters, ${ }^{6}$ the following data focus on the Spanish civil justice system and are taken from the statistics yearly provided by the CGPJ. ${ }^{7}$ They show the number of civil courts, the number of incoming cases and caseload in different stages of the proceedings, as well as the length of the procedure.

The civil justice system is organised in 431 judicial districts with 895 single judge courts, including courts of first instance (a few of them specialised in family matters in big cities and others also in charge of criminal enquiries in some small cities) and commercial courts, and 95 collegiate bodies, i.e. provincial high courts with a civil chamber, superior courts of justice with a civil and criminal chamber, and the Supreme Court whose first chamber is devoted to civil matters. The number of judges is 3,999 , although the figure includes all judges dealing with civil and criminal matters. All in all, the percentage of members of the judiciary per 100,000 inhabitants is 11.5 .

In 2014 civil courts handled 1,845,173 incoming cases, resolved 1,858,579 cases, and left pending 1,009,392 cases, and 484,751 judgments were pronounced. As to enforcement of judgments, in 2014 civil courts received 621,226 incoming cases, resolved 595,691 cases, and left $2,023,465$ cases pending at the end of the year. However, these data have been heavily criticised on account of

6. Kramer and Kakiuchi, above n. 4

7. See The Spanish Judiciary in Figures 2014. Judicial Statistics, available at $<$ www.poderjudicial.es $>$. 
the planning and design survey. ${ }^{8}$ Noteworthy is that the abovementioned data label as 'incoming cases' all type of proceedings - including those ancillary to others such as incidental proceedings or provisional measures; appeals, cassation, and other challenges; or even payment proceedings that end up in a declaratory one - so that the same case counts more than once. ${ }^{9}$ The point made by this criticism is worth being pursued to the extent that an inappropriate design survey does not provide a real picture of the Spanish justice system, i.e. of which are the weak points and, thus, of how to solve them. While this study goes back to 2013, nothing has changed in the CGPJ's modus operandi since then.

In a similar vein, it is not easy to calculate the real length of the procedure due to the lack of accurate statistical official information. According to the same source provided by the CGPJ, the length of the procedure in courts of first instance was about 7.3 months in 2009, but descended abruptly in 2014 to 6.2 months. In commercial courts such a length is much longer and has been steadily growing from 20.3 months in 2009 to 40 months in 2014. As to the second instance, the average duration is around 6 months for the same period. ${ }^{10}$

Even with all abovementioned caveats, these figures justify the need of more judges in Spain and provide the background against which to assess the measures undertaken by the Government in the age of austerity and that are examined in the third part of this article. But there may be more reasons behind the length of the procedure and one of them could be the amount of paper to be handled by courts. While important steps have been taken to implement the information technology in the system, ${ }^{11}$ the digitalisation of procedure has been literally patchy in Spain due to the fact that each Comunidad Autónoma applies a telematic system. Coordination depends on the Central Government and Action Plans have been issued with this goal in task, but the issue has not been completely solved yet.

\subsection{Average Costs of Civil Procedure}

The more expensive, the more difficult is to get access to justice. In order to assess other measures undertaken in the age of austerity, a brief reference to the average costs of civil procedure in Spain, which are very variable, seems to be necessary. The amount is usually around the $10 \%$ of the economic interest of the procedure, but in cases in which subject matters of less than

8. See Report on the resorting to, and elaboration of, statistics by the CGPJ, prepared by the Universidad Autónoma de Madrid in 2013 and published by the CGAE, available at <www.abogacia.es/2013/07/24/ situacion-actual-de-la-administracion-de-justicia-en-espana-un-analisisdesde-el-derecho-procesal/>

9. According to this study, only around 700,000 cases could be labeled as 'incoming cases', once all abovementioned duplicities are avoided.

10. These data can be contrasted with those provided by the 2014 EU Justice Scoreboard, above n. 5, Figure 2.

11. The Organic Law 16/1994, of 8 November, amending the LOPJ, already provided the legal basis to modernise the justice system being now key to this end, Law 18/2011, of 5 July, on the use of the information and communication technology in the justice administration (BOE No. $160,6.7 .2011$ ).
$10,000 €$ are discussed, the costs may be around 2,000-5,000€..$^{12}$

The Spanish system is organised according to the principle 'the loser pays', whereas the 'winner' does not take it all, but a big part of the costs. That includes lawyers and procuradore' fees; costs linked to proofs such as experts' and notaries' fees, copies, certifications, etcetera; and court fees, deposits to challenge judgments, payments for announcements or public announcements, preventive annotations of lawsuits or embargos, deposits of goods, etcetera. However, other costs are not recoverable from the litigant who loses, i.e. pre-trial costs such as previous legal advice, extra-procedural activities, costs to gather proofs, and any other payments related to the proceedings.

Noteworthy is that lawyers' and procuradores' fees are only recoverable if their participation in the proceedings is mandatory, which is otherwise the rule in Spain. One exception is that of litigation of small matters through simplified proceedings provided that the claim is under $2,000 €$. Other exceptions where the assistance of a lawyer is not mandatory concern particular actuations, namely, the initial application for an order for payment, the application for taking part in proceedings already initiated, or requesting urgent measures before the beginning of proceedings or the urgent suspension of a hearing or particular events. ${ }^{13}$

In addition to a lawyer, parties to proceedings need a procurador. Related to the personero named in Las Partidas by Alfonso $\mathrm{X}$ 'the Wise' in the twelfth century and to the procurator of Roman Law, the procurador de los tribunales has been legally representing individuals in court ever since, playing a complementary role to the lawyers' tasks of providing clients with legal advice and defence. ${ }^{14}$ Anyway, parties to a civil proceeding must be represented by a procurador along with a lawyer save some cases as well, ${ }^{15}$ namely, simplified proceedings dealing with claims under 2,000 $€$ and specific actuations, such as the initial application for an order for payment; claim filing or participation in meetings in the framework of universal proceedings; provision for legal aid; or those cases in which urgent measures are requested before the commencement of the proceedings.

Despite these fees, the standardisation of procedure with the aim of cost reduction does not seem to be on the legal agenda, ${ }^{16}$ and standard forms are being resorted to in just very specific cases. For example, a debtor natural person that intends to apply for a debt discharge is advised to fill in a standard form to request negotiations to reach an out-of-court restructuring plan and to

12. These figures are only indicative. They have been concluded in particular taking into account the guidelines on lawyers' fees provided by bar associations and available at their webpages.

13. See Art. 31 LEC.

14. In the Middle Age its role was similar to the barristers' in English Law, but it evolved very differently along the centuries as it was little by little perceived as a subject whose task was only that of assisting lawyers, mostly being in charge of obtaining notices and summons for their clients and meeting legal deadlines.

15. See Art. 23 LEC.

16. See on this trend Kramer and Kakiuchi, above n. 4, at 50. 
provide the lists of her assets and liabilities. ${ }^{17}$ Apart from other exceptional cases, standard forms are mostly linked in Spain to the application of European Regulations.

\section{Budget Restrictions on the Grounds of the Economic Downturn}

\subsection{The Freeze on the Hiring of Judges}

Unlike other countries where becoming a judge is the culmination of a successful professional career, the Spanish system requires applicants to pass qualifying exams that require extensive preparation and afterwards undergo a training period at a corporate school. Accordingly, becoming a judge is a long process in Spain, but one which is mostly undertaken by young bachelors: the average time of preparation is 4.5 years after getting the law degree while the training period lasts for a year, being 30 years old the average age to become a judge. ${ }^{18}$ Noteworthy is that most of them have not worked before and those that have were not employed in the law field.

Legal professionals such as lawyers with more than 10 years of practice may become judges passing a specific examination, but the abovementioned open competition is the usual door to enter into the judicial career. The latter has been largely contended on the grounds of mostly relying on a rote-learning approach to ensure that those selected meet the principles of merit and capability as required by the Spanish Constitution ${ }^{19}$ and thus disregarding other abilities that a judge must have. Nevertheless, the debate between supporters and opponents has only led to a minor modification of the open competition, ${ }^{20}$ by including the arguing and solving cases to show know-how and not only knowledge. ${ }^{21}$

Other changes have been proposed and were under discussion when the economic downturn broke out in Spain. They focused on the socio-economic origin of applicants acknowledging the fact that applicants have

17. This possibility is available only to debtors' natural persons with liabilities under 5 mil. $€$ and legal persons that may resort to the fast-track procedure laid down in Art. 190 of the Law 22/2003, of 9 July, on Insolvency, the Ley Concursal (hereafter, LC). The use of standard forms is laid down in Art. 232(2) thereof.

18. Data are from 2003 to 2014 and taken from statistics provided by the CGPJ available at $<$ www. poderjudicial.es $>$.

19. Art. 103(3) of the Spanish Constitution establishes that both principles are at the core of access to the judiciary being then further developed in Arts. $301 \mathrm{ff}$. LOPJ.

20. See as examples of these contradictory viewpoints G. Quintero Olivares, 'Judges and Prosecutors, between selection and recruitment', 3 Education and Law Review (2011), available at <http://revistes.ub.edu/ index.php/RED/article/view/1778/2349> and J. Jaria i Manzano, 'Selection, Professional Profile and Initial Training of Judges in Spain', 3 Education and Law Review (2011), available at <http://revistes.ub.edu/ index.php/RED/article/view/1780/2353>.

21. As mentioned by the White Book on Justice edited by the CGPJ in 1998. Available at <www.icam.es/docs/ficheros/201202170003_6_0. $\mathrm{pdf}>$ to study for a long period during which they do not earn any money; this has an impact on future judges' background to the extent that not all social classes and thus not all sensibilities are represented in the judiciary. Against this background, it is to highlight that the Spanish Constitution does not only lay down the principle of equality and the prohibition of any kind of discrimination, but also the obligation to promote the necessary conditions to make it feasible. ${ }^{22}$ Accordingly, the establishing of a grant system has been discussed in recent years, ${ }^{23}$ but unfortunately, it has never gone beyond this stage, due to the economic downturn among other reasons. $^{24}$

Anyway, Spain has made a great effort to improve and modernise the judicial system in the last 30 years, including a relevant increase of the number of judges. Taking into account the abovementioned usual mode of becoming a judge, the need of incentivising applicants has also played a role in this, and a significant offer of judge positions has been made on a yearly basis for almost 20 years. ${ }^{25}$ Despite this, the number of judges in Spain is still a low one compared to other countries in Europe. According to data provided by the CGPJ in 2014, there are 11.5 judges per 100,000 inhabitants, while the European rate is 19.8. In fact, the economic downturn broke down the efforts already made to overcome this gap to the extent that one of the austerity measures adopted by the Government was the freeze of public employment. Accordingly, while 400 judge positions were offered in 2010 and 2011, there was no call for applications in 2012 and only 100 positions were offered in the years 2013 and 2014. ${ }^{26}$ Furthermore, the hiring of substitute or deputy judges to cover temporary vacancies of professional judges has been stopped as well.

Noteworthy is that last statistics provided by the CGPJ showed a slight increase in the abovementioned rate in

22. See Arts. 14 and 9(2) of the Spanish Constitution, respectively.

23. See for all, M.J. Collado Nuño, 'Access to the Judicial Career in Spain', 3 Education and Law Review 1, at 4 (2010). Available at <http://revistes. ub.edu/index.php/RED/article/view/1777/1762>.

24. Other issues have been totally disregarded during these years being noteworthy the lack of attention to the impact of the Bologna system in Spanish legal education. As known, the Bologna Declaration promotes a system made of a bachelor degree and a master. Spain follows now this system, but only one professional master has been set up, by which entry to the legal professions of lawyer and procurador de los tribunales has been regulated. The case of judges has not been targeted yet, despite acknowledgment of this issue. See F. Galindo Ayuda, 'La formación de los jueces', 7896 Diario La Ley (2012), available at <http:// diariolaley.laley.es>, and in particular 'El CGPJ abre el debate sobre el acceso a la carrera judicial y se plantea solicitar que los opositores sean máster', 7551 Diario La Ley (2011), available at <http://diariolaley. laley.es>. See discussing this issue L. Carballo Piñeiro, 'Legal Education in Spain: Challenges and Risks in Devising Access to the Legal Professions', 19 International Journal of the Legal Profession 339, at 347 (2012)

25. According to Art. 306 LOPJ, a call for application is to be made at least each 2 years. Since 1998, the call for applications is made on a yearly basis.

26. Mort recent calls for applications are available at $<$ www.poderjudicial. es>. 
relation to that in $2013 .{ }^{27}$ The reasons have to be found in the loss of population undergone by Spain as a result of the economic downturn while a considerable number of legal persons has disappeared. ${ }^{28}$ In a similar vein, legal reforms are shifting some competencies from judges to other legal professionals. ${ }^{29}$ While some of them can be contended, the number of cases to be handled by Spanish judges accordingly diminishes. Nevertheless, what cannot be contended is that public investment in justice has been dramatically reduced, from $90 €$ inhabitant/year in 2010 to $25 €$ in $2012 .{ }^{30}$ And it is only this year that a slight increase in the budget has been promised.

\subsection{The Establishing of Court Fees}

Court fees were totally abolished in Spain in $1986^{31}$ in accordance with a wide interpretation of the principle of freedom from costs laid down in the Spanish Constitution. ${ }^{32}$ In 2002 they were reintroduced, but only for legal persons and in the framework of civil and administrative proceedings,${ }^{33}$ thereby setting aside natural persons. However, they were extended to every user of the judicial system in 2013 on the grounds that access to justice is a service and those interested in using it have to pay for it. ${ }^{34}$ In fact, the Explanatory Introduction to Law $10 / 2012$ by which they were established makes it clear that court fees are determined taking into account the costs of providing justice and not the economic capability of the tax payer, the latter being in contradiction with the principle of economic capability enshrined by the Spanish Constitution. ${ }^{35}$

Court fees were made up of a fixed ${ }^{36}$ and a variable quantity, the latter consisting of a percentage applicable

27. From 11, 1 judges per 100,000 inhabitants in 2013 to 11, 5 in 2014. See The Spanish Judiciary in figures 2013, at 13. Available at <www. poderjudicial.es>.

28. See Report on the resorting to and elaboration of statistics by the CGPJ, prepared by the Universidad Autónoma de Madrid in 2013 and published by the EU Justice Scoreboard, above n. 7, at 6 contending that litigation has returned to 2007 figures.

29. See on further problems concerning the court office J. Nieva Fenoll, 'Reformas pasadas y reformas pendientes del proceso civil español', 8513 Diario La Ley 1 (2015).

30. Both data are taken from The 2014 EU Justice Scoreboard, above n. 5, at 22 and 23.

31. See Law 25/1986, of 24 December (BOE No. 313, 31.12.1986)

32. Art. 119 of the Spanish Constitution.

33. Ley 53/2002, de 30 de diciembre, de Medidas Fiscales, Administrativas y del Orden Social (BOE No. 313, 31.12.2002).

34. See Ley 10/2012, de 20 de noviembre, por la que se regulan determinadas tasas en el ámbito de la Administración de Justicia y del Instituto Nacional de Toxicología y Ciencias Forenses (en adelante Ley de Tasas), desarrollada por la Orden HAP/2662/2012, de 13 de diciembre (BOE No. 280, 21.11.2012).

35. See Art. 31(1) of the Spanish Constitution. Another issue was that taxable events were not clearly determined in Law 10/2012 giving rise to legal uncertainty. On both grounds, the Government issued immediately after the entry into force of Law 10/2012, Royal Decree Law 3/2013, of 23 February (BOE No. 47, 23.2.2013), amending the calculation of court fees to be paid by individuals and some aspects of the Law 1/1996, of 10 January, on Legal Aid (Ley de Asistencia Jurídica Gratuita) with a view to line up both laws. See criticism by C. Martínez Sánchez, 'Una aproximación crítica a las tasas judiciales desde el derecho financiero y tributario', 27 Revista Jurídica de la Universidad Autónoma de Madrid 205 (2013). over the claim's quantity. ${ }^{37}$ Second and third instances were far more expensive than the first one to the extent that only the fixed part of the fee amounted to $800 €$ in case of an appeal and to $1200 €$ in case of cassation. As a matter of fact, the impact of these high court fees was especially clear in the access to the second instance putting in question the right to appeal. In general, the reform discouraged individuals from resorting to courts and endangered effective access to justice, ${ }^{38}$ for which reason the reform was challenged before the Constitutional Court. ${ }^{39}$ While court fees are not in principle against any constitutional right, it all depends on whether they impair access to justice due to their high amount. ${ }^{40}$ And when assessing these fees, it must be taken into account that the minimum salary in Spain is $648.80 €$ per month. ${ }^{41}$

Bar associations and lawyers were very active against court fees as civil society was against them: a survey of 27 November 2012 founded by the CGAE concluded that $83 \%$ of the Spanish society was against it. ${ }^{42}$ On the grounds of the general discontent, the Government finally amended Law 10/2012; ${ }^{43}$ while court fees for legal persons are maintained, a significant number of exclusions have been laid down on both objective ${ }^{44}$ and

36. See Art. 7 of Law 10/2012. The fixed part of the fee was the following: simplified and summary procedures, $150 €$; ordinary procedure, $300 €$; orders for payment procedures and claims in the framework of insolvency proceedings, $100 €$; extrajudicial enforcement and opposition to judicial enforcement, $200 €$; mandatory insolvency proceedings, $200 €$; appeal, $800 €$; cassation, $1200 €$.

37. In case of individuals the variable part of the court fee was $0.10 \%$ over the value of the claim, with a maximum of $2,000 €$. In case of legal persons, from 0 to $1,000,000 €$ that percentage is $0.5 \%$ and from that quantity on, $0.25 \%$. The maximum of this variable part of court fees is $10,000 €$.

38. Judicial statistics confirms that court fees discouraged access to justice, their impact being particularly relevant when it comes to challenging a judgment. In 2013 the number of incoming cases before courts of first instance was $12.0 \%$ less than in 2012 while that figure before Provincial High Courts-Civil Division (dealing with appeals) was $20.2 \%$ less than in 2012, and a $15.5 \%$ less before High Courts, 1st Chamber. See Judicial Statistics, above n. 7, at 41 and A. Egea de Haro, 'Una aproximación al efecto de las tasas sobre el nivel de litigiosidad. Placebo y realidad', 8498 Diario La Ley 1, at 5 (2015).

39. See questions of constitutionality No. 5173-2013, No. 1628/2013, No. 5438-2013, and No. 905/2014; and constitutionality challenges No. 973-2013 and No. 1024-2013, No. 4948-2013, and No. 4972-2013.

40. See judgment of the Constitutional Court 20/2012, of 16 February, and F. Álvarez-Ossorio Micheo, 'Tasas judiciales: entre principio de proporcionalidad y política de derechos humanos', 100 Revista Española de Derecho Constitucional 221(2014). Remarkable is the decision taken by some courts of not applying the court fee on the grounds of the litigant's economic situation and the rights at stake, as it happens in the case decided by Auto de la Audiencia Provincial Pontevedra, 20 July 2014, available at <www.poderjudicial.es/cgpj/es/Poder-Judicial/Salade-Prensa/Notas-de-prensa/-La-Audiencia-de-Pontevedra-exime-a-unrecurrente-de-pagar-la-tasa-judicial-por-considerarla-inaplicable $>$.

41. See Royal Decree 1106/2014, of 26 December (BOE No. 313, 27.12.2014), fixing an inter-professional minimum salary for 2015.

42. Available at <Www.abogacia.es/wp-content/uploads/2012/11/METRO SCOPIA-INFORME-TASAS.pdf>

43. Royal-Decree 1/2015, of 27 February (BOE No. 51, 28.2.2015).

44. They are enumerated in Art. 4(1) of Law 10/2012, including the request for voluntary bankruptcy by the debtor, or initial request for a payment order procedure and demand in the verbal proceeding when the amount thereof do not exceed 2,000 € 
subjective ${ }^{45}$ grounds. Noteworthy is that natural persons are now excluded from the payment of court fees.

\section{The Impact of Austerity Measures}

\subsection{The Situation of Legal Aid and the Exclusion of Litigants from the System}

The right to legal aid is constitutionally acknowledged in Spain and further regulated by Law 1/1996. ${ }^{46}$ Legal aid covers all kind of procedures, including legal advice prior to the commencement of a proceeding. While this right can be claimed by any Spanish and EU citizen, ${ }^{47}$ foreign citizens may apply for it only when residing in Spain, save some international treaties. Some legal persons are also granted legal aid when it comes to specific claims, such as consumer associations with a view to bringing collective actions before courts or in general, foundations and associations serving public interests.

In order to get legal aid, applicants must basically meet two requirements, ${ }^{48}$ namely, litigating on own matters and lacking resources to litigate. Applicant's economic resources are measured according to an indicator regulated by Royal Decree Law 3/2013; while the maximum income per month was twice the minimum wage, the latter has been substituted by the so-called public revenue index which has been growing at a lower rate than the minimum wage, making it difficult for families in difficulties to get access to legal aid. Furthermore, it must be borne in mind that this index remains 'frozen' since 2010. ${ }^{49}$ The income of the applicant must be less than twice this index when the family consists of only one person, two and a half when there are less than four family members, and three times in case they are more than four. While the general rule is that the right to legal aid is allocated according to the economic situation of applicants, a flexible mechanism of subjective appreciation has been established, allowing the exceptional recognition of the right to those whose economic resour-

45. Pursuant to Art. 4(2) of Law 10/2012, exemptions on subjective grounds are the following: (a) natural persons; (b) legal persons who have been granted the right to legal aid; (c) the Public Ministry; (d) the General State Administration, the Autonomous Regions, local authorities, and the employees of all public bodies; (e) the Parliament and the legislative assemblies of the Autonomous Regions.

46. Art. 119 of the Spanish Constitution establishes that, pursuant to the corresponding law, those without enough resources to litigate must have legal aid. This fundamental right has been legally developed by the abovementioned Law 1/1996 on Legal Aid, amended by the said Royal Decree Law 3/2013, modifying the system of fees in the framework of the justice administration and the system of legal aid. Last amendment was undertaken by Law 42/2015 of 5 October.

47. Chapter VIII of the Law 1/1996 transposes into Spanish law Council Directive 2002/8/EC, of 27 January 2003, to improve access to justice in cross-border disputes by establishing minimum common rules relating to legal aid for such disputes.

48. See Art. 3 of the Law 1/1996.

49. The exact amount is available at the following webpage: <www.iprem. com.es/>. A distinction is made between a monthly public revenue index or IPREM (532.31 €), a 12-month IPREM (6,390.13 €), and a 14month IPREM $(7,455.14 €)$. ces exceed the abovementioned maximum and hence are not eligible for coverage, but whose personal circumstances make it advisable to granting them legal aid, provided that they do not earn more than five times the public revenue index.

The system is financed by the State, but carried out by the bar associations, and their General Council, the CGAE, regularly publishes statistics on the functioning of the system. ${ }^{50}$ In 2012,232 mill.€ were invested in the system, meaning this figure a reduction of a $8.7 \%$ in respect to 2011 (254.5 mill. €). In 2010 (256 mill. €) the reduction was of $4 \%$ in regard to 2009 (266 mill. €). Data from the year 2013 indicate that investment in legal aid continues to decrease in another $4 \%$, i.e. 223.5 mill. $€{ }^{51}$ It must be noted that the reduction has mainly affected payments to lawyers to the extent that they have taken a between 5 and $10 \%$ pay cut depending on the Comunidad Autónoma. ${ }^{52}$ In contrast, the investment in the system has been increased a $1.5 \%$ in 2014 (226.9 mill.€) as a result of the widening of litigants with right to legal aid following the introduction of court fees and their impact on access to justice. ${ }^{53}$ So, all that can be said is that the trend towards a declining investment has been just simply slowed down.

\subsection{The Impact of Austerity on the Behaviour of Litigants: The Resorting to Self-Defence Mechanisms in Light of the Non-Efficient State Action}

In recent years there has been a dramatic increase in the number of court cases, in particular of those related to insolvency and debt collection cases. ${ }^{54}$ The point to be made now is that, unfortunately, the Spanish civil justice system did not provide families in difficulties for alternatives and led them to situations of social exclusion. In view of lack of State support, citizens have been

50. The following figures can be found in the studies provided by the CGAE $<$ www.abogacia.es/wp-content/uploads/2013/07/VII-ObservatorioJusticia-Gratuita.pdf> and <www.abogacia.es/wp-content/uploads/ 2014/07/IX-Observatorio-Justicia-Gratuita-y-portada.pdf>.

51. See VIII Informe del Observatorio de Justicia Gratuita. Abogacía Española-LA LEY. Estadística completa 2010-2013, available at <www. abogacia.es/repositorio/viii_observatorio_justicia_gratuita/offline/ download.pdf>.

52. Although those payments were not already high as a lawyer receives around $125 €$ per file.

53. The same CGAE reports inform that applications for legal aid have significantly increased in 2014 and 2013: 969,775 and 950,000 applications were respectively filed those years while the figure was 800,000 in 2012. The explanation to this rise can be found in the introduction of significant court fees in Spain in 2013. It has boosted the said number of applications, in particular in those claims against public administrations where the applications in 2013 raised a 54\% in relation to the previous year; in civil matters, the increase was of $16 \%$ in the same period of time. Figures are similar in 2014. All in all, 1,770,000 cases were handled within this system in 2013 and 1,765,000 in 2014. To understand such figures account should be given to the fact that those granted legal aid may give rise to different files, from proceedings in first instance to challenges, etc.

54. Again, data on the crisis and courts' workload from 2007 to the beginning of 2015 can be downloaded from the CGPJ webpage <www. poderjudicial.es/cgpj/es/Temas/Estadistica-Judicial/Informes-estadisticos -periodicos $>$. It provides information on number of enforcement, insolvency and payment proceedings, as well as those related to mortgages or evictions. 
organising themselves in platforms of people affected by mortgages. ${ }^{55}$ These platforms provide legal advice and counselling, but also support to those families whose situation is that of becoming homeless. Remarkably, they have openly resorted to illegal occupation of buildings to provide households accommodation. The legal situation has slightly improved, but Spain is still far away from complying with citizens' expectations, for which reason many people still depend on these platforms to get shelter.

The Government has only reacted to the eviction problem after a 2013 judgment of the Court of Justice of the European Union condemning Spain, ${ }^{56}$ by issuing immediately after a law adopting some measures to mitigate the situation of debtors in difficulty of paying back the mortgage over their home. ${ }^{57}$ This law allows the immediate suspension and for a 2-year-period, of evictions of those families in 'situation of special risk of social exclusion', and provides for a limitation on the interest rate in case of late payments. However, this is an exceptional and temporal measure which does not interfere with mortgage enforcement proceedings, and it is only available for numerous families or families made of an only parent with at least two children, for those with a 3year-old minor or some disabled or dependent members, for unemployed debtors and deprived of any social benefit, or for victims of gender violence. Along with further requirements, their income must not exceed three times the public revenue index, and the significant difficulties must have begun at least 4 years before the claim for suspension of eviction.

As to the proceeding, the said 2013 law specifically lays down the obligation of judges and notaries - the latter, when extra-judicially selling out the house - of examining ex officio the existence of unfair terms in the contract of mortgage. This modification has been adopted following the CJEU case law in its judgment of 14 March $2013,{ }^{58}$ specifically addressing a prejudicial question posed by the Commercial court No. 3 of Barcelona as regards to Directive 93/13/EEC. ${ }^{59}$ The CJEU rules out inter alia that the Directive

must be interpreted as precluding legislation of a Member State, such as that at issue in the main proceedings, which, while not providing in mortgage enforcement proceedings for grounds of objection based on the unfairness of a contractual term on which the right to seek enforcement is based, does not allow the court before which declaratory proceedings have been brought, which does have jurisdiction to assess whether such a term is unfair, to grant inter-

55. See Plataforma de Afectados por la Hipoteca <http://afectadosporla hipoteca.com/>.

56. Case 415/11, Mohamed Aziz v. Caixa d'Estalvis de Catalunya, Tarragona i Manresa (Catalunyacaixa), [2013] ECLI:EU:C:2013:164.

57. See Ley $1 / 2013$, de 14 de mayo, de medidas para reforzar la protección a los deudores hipotecarios, reestructuración de deuda y alquiler social (BOE No. 116, 15.5.2013)

58. Case $415 / 11$, above n. 56

59. See Council Directive 93/13/EEC of 5 April 1993 on unfair terms in consumer contracts [1993] OJ L 95/29. im relief, including, in particular, the staying of those enforcement proceedings, where the grant of such relief is necessary to guarantee the full effectiveness of its final decision.

This judgment has been largely celebrated in Spain to the extent that it has helped to unveil significant abuses in mortgage contracts that were being executed or burden household economies. Yet, mortgage realisations go on and consist of the selling out of the house, many times for a prize under the debt. For this reason the 2013 law opens the way to a writing of a part of the debt in exchange for certain payments and the mechanisms of bidding and auction have been improved to facilitate the participation of bidders.

Despite its rhetoric, the 2013 law is too restrictive and timid when addressing this important social problem. For example, and despite the clear CJEU's case law, it established a time limit to claim that the mortgage contract contains unfair terms, for which reason it was challenged before the CJEU which concluded that this is contrary to Directive $93 / 13 / \mathrm{CEE} .^{60}$ For this and other reasons, the 2013 law has been amended in $2015 .{ }^{61}$ Noteworthy is that debtors over sixty are now considered especially vulnerable ${ }^{62}$ and a small increase in the maximum income under which families would be included in the scope of this law has been done, by taking into consideration the public revenue index of fourteen salaries. ${ }^{63}$ Yet, amendments are not relevant and they will not increase the (small) number of beneficiaries. ${ }^{64}$ Against this background, it was particularly striking that natural persons were not able to resort to insolvency law to overcome their economic problems; while the Spanish Insolvency Act did not distinguish between debtors and thus it is applicable to everyone, proceedings' costs made it impossible for small debtors to take advantage of it, thereby social exclusion and the resorting to informal economy were the only alternatives for many professionals and private persons. On account of the new approach to failure promoted by the European Union, ${ }^{65}$ the Spanish Insolvency Act has been finally amended to make it possible a second chance for natural persons, including consumers. ${ }^{66}$ The terms in which the debt discharge is laid down are not the most favourable, but

60. Case C-169/14, Sánchez Morcillo and Abril García [2014] ECLI:EU:C: 2014:2099

61. In particular, by Royal Decree 1/2015, 27 February.

62. See Art. 1 of Law 1/2013 laying down the concept of 'person especially vulnerable'.

63. In detail, see Art. 1(3) of Law 1/2013.

64. The same law has also been amended with a view to taking into account the many judgments in Spain declaring many mortgage contract terms unfair. In this regard, it must be mentioned that Directive 2014/17/EU of the European Parliament and of the Council of 4 February 2014 on credit agreements for consumers relating to residential immovable property and amending Directives 2008/48/EC and 2013/36/EU and Regulation (EU) No. 1093/2010 [2014] OJ L 60/34) has not been transposed in Spain yet.

65. See, e.g. Commission Recommendation of 12 March 2014 on a new approach to business failure and insolvency [C(2014) 1500 final].

66. See in particular, Art. 178bis LC. 
it is a significant step forward in relation to the former situation.

\section{The (Non-)Alternative Measures Envisaged to Improve the Civil Judicial System}

\subsection{Mediation}

Spain has joined the global trend towards favouring mediation and other alternative dispute resolution methods to the extent that they seem to be a good alternative to an increasingly impoverished and expensive judicial system. ${ }^{67}$ ADR methods were, of course, not strange to the Spanish legal system, ${ }^{68}$ but it cannot be said that they had been successful. For example, a conciliation proceeding was introduced in 1996, to be followed before the civil proceeding and conducted by the seized judge acting thus as a conciliator. ${ }^{69}$ What happened is that the judge was in general not present in the conciliation hearing and the intervention of the applicant for conciliation was limited to explain the facts asking the other party to admit them. As the latter did not do it, the formality of having attempted conciliation was deemed to be satisfied, and therefore, the opening of civil proceedings proceeded. ${ }^{70}$ Not surprisingly, judicial settlements were also and still are a rara avis in Spain, although the lawyers' role as social mediators, i.e. helping clients to avoid litigation, must be highlighted here. ${ }^{71}$ The point to be made is that, on the one hand, parties' transaction is difficult to achieve once the stage of litigation has been reached, while on the other hand, members of the judiciary are not fully convinced that they have a role to play when it comes to ADR methods. Nevertheless, the costs of the justice system along with the international move towards ADR methods brought to the forefront the need of convincing Spanish society

67. See Kramer and Kakiuchi, above n. 4, at 49-50.

68. An embryo of mandatory conciliation was already mentioned in Art. 282 of the 1812 Constitution of Cádiz for civil lawsuits and slander cases, available at <www.congreso.es/portal/page/portal/Congreso/ Congreso/Hist_Normas/ConstEsp1812_1978/Const1812>.

69. See Arts $460 \mathrm{ff}$. of the Royal Decree of 3 February 1881 issuing the Ley de Enjuiciamiento Civil (Gaceta 5 February 1881)

70. J. Nieva Fenoll, Derecho procesal II: Proceso civil (2015) at 121

71. According to a survey conducted by the CGAE in 2008 , only $60 \%$ of cases actually reach the courts. See 'La Abogacía española en datos y cifras 2008', at 146-7 and at 161. Available at <www.cgae.es/ portalCGAE/archivos/ficheros/1225374383601.pdf> to turn to these mechanisms. ${ }^{72}$ In this regard, Directive 2008/52/EC of European Parliament and of the Council, of 21 May 2008, on certain aspects of mediation in civil and commercial matters ${ }^{73}$ speeded up this process, and in addition to a law transposing it, ${ }^{74}$ other laws have been amended to encourage the resorting to mediation. In particular, the LEC was amended to make courts inform parties to the proceedings that they have the path of mediation open. ${ }^{75}$ In a similar vein, the abovementioned conciliation proceeding has been abolished and a new one established to which parties may resort prior to the beginning of the judicial process. ${ }^{76}$ Mediation is also possible in the course of judicial proceedings, but the judge has in this case a passive role. ${ }^{77}$

All these legal changes along with the political will and an intense academic debate have clearly given a boost to mediation in Spain, but only in terms of legislation and in offers of training courses for mediators. In order to become a mediator, a specific training is compulsory for which reason many institutions, in particular universities and bar associations, have provided for it and almost every lawyer and other professionals have been qualified as mediators. ${ }^{78}$ As said, legal reforms have made courts advise mediation and specific programs have been established to fulfil this obligation. As a result, figures on mediation in family matters have been relatively improved. ${ }^{79}$ As to other matters and save the case of ADR methods in labour matters, there are not reliable

72. In 2008, a plan to modernise the justice administration was approved by the CGPJ including civil and criminal mediation as part of it. See Plan de Modernización de la Justicia available at <www.poderjudicial.es/ cgpj/es/Temas/Modernizacion-de-la-Justicia/El-Plan-de-Modernizacion -de-la-Justicia>. See S. Barona Vilar, Mediación en asuntos civiles y mercantiles en España. Tras la aprobación de la Ley 5/2012, de 6 de julio (2013), at 51 and at 76, on further manifestations of mediation in Spain, including legislation issued by the regional Parliaments of the Spanish Comunidades Autónomas and sector-oriented mediation process conducted by Ombudsmen, e.g. in insurance or education matters.

73. OJ [2008] L 136/3. In the same vein, see Directive 2013/11/EU of the European Parliament and of the Council of 21 May 2013 on alternative dispute resolution for consumer disputes and amending Regulation (EC) No. 2006/2004 and Directive 2009/22/EC, OJ [2013] L 165/63 and Regulation (EU) 524/2013 of the European Parliament and of the Council of 21 May 2013 on online dispute resolution for consumer disputes and amending Regulation (EC) 2006/2004 and Directive 2009/22/EC (Regulation on consumer ODR), OJ [2013] L 165/1.

74. See Ley 5/2012, de 6 de julio, de mediación en asuntos civiles y mercantiles (BOE No. 162, 7.7.2012).

75. See Arts. 414(1), 440(1), 443(3) LEC

76. See Arts. 139-148 of Law 15/2015.

77. See Art. 415 LEC. The difference between conciliation and mediation is in Spain as blurred as in other countries. See J. Nieva Fenoll, 'La mediazione: un'alternativa ragionevole al processo?', 67 Rivista Trimestrale Di Diritto e Procedura Civile 1327, at 1329-1332 (2013), who also emphasises the non-convenience of naming conciliator the very same judge to decide on the case, but a different one on account of their auctoritas reinforcing their persuasion ability. Ibid., at 1336-1339.

78. On the significant of mediators' education, see ibid., at 1332-1336.

79. According to data provided by the CGPJ on mediations undertaken in the course of family proceedings in 2014, family courts have referred to mediation 6,101 cases, 1,379 were mediated and 598 ended up in settlement while 781 not. See 'Mediación intrajudicial en España 2014', available at <www.poderjudicial.es/cgpj/es/Temas/Mediacion/Datosestadisticos/Mediacion-intrajudicial-en-Espana--datos-2014>. 
data ${ }^{80}$ but the reality seems not to be as good as expected by all the fuss around mediation. ${ }^{81}$ For it is true that much has to be improved, there are also justified worries that it will only serve to increase the length of the procedure.

\subsection{Consumer Arbitration}

Consumers' access to justice is an issue that highly preoccupies modern democracies to the extent that their claims are usually of such a low value that it is not worth litigating. Yet, should consumer rights remain unclaimed, unfair competition issues would arise and consumer diffidence would impair the correct functioning of the market. Against this background, several techniques have been resorted to with a view to facilitating consumers' access to justice, including ADR methods. Spain is not an exception, although its system can only be understood in the framework of EU law.

As known, the European Union has been especially active in consumer law. For our purposes Council Directive 93/13/ECC of 5 April 1993 on unfair terms in consumer contracts is to be again mentioned to the extent that it lays down that arbitration agreements included in this type of contracts are to be considered null and void unless covered by legal provisions. ${ }^{82}$ As a matter of fact, the establishment of an administrative system of consumer arbitration by the Government was already planned in $1984,{ }^{83}$ but it was only set up in $1993 .^{84}$

80. The study 'Rebooting the Mediation Directive: assessing the limited impact of its implementation and proposing measures to increase the number of mediations in the EU', prepared in 2014 by the DirectorateGeneral for Internal Affairs, European Commission, and available at <www.europarl.europa.eu/RegData/etudes/etudes/join/2014/493042/ IPOL-JURI_ET\%282014\%29493042_EN.pdf>, is quite clear in this respect: mediation in civil and commercial matters has been used only in less than $1 \%$ of the cases in the EU. In Spain, from 500 to 2,000 mediations have been estimated per year. See ibid., at 6, Figure B.

81. See an overview of mediation's pros and cons in S. Barona Vilar, 'Integración de la mediación en el moderno concepto de Access to Justice. Luces y sombras en Europa', InDret 1 (2014), available at <www.indret. com/pdf/1092.pdf>.

82. Annex to Directive 93/13/ECC includes within the terms referred to in Art. 3(3)1, i.e. those that are null and void, terms '(q) excluding or hindering the consumer's right to take legal action or exercise any other legal remedy, particularly by requiring the consumer to take disputes exclusively to arbitration not covered by legal provisions, unduly restricting the evidence available to him or imposing on him a burden of proof which, according to the applicable law, should lie with another party to the contract'.

83. Consumer protection is to be pursued by any state institution or private person in Spain, pursuant to Art. 51 of the Spanish Constitution. Against this background, Art. 31 of the Ley 26/1984, de 19 de julio, general para la defensa de los consumidores y usuarios laid down the Government's obligation to set up an arbitration system taking into account any interested party's opinions, in particular those of consumer associations.

84. The Consumer Arbitration System was set up by Royal Decree $636 / 1993$ of 3 May 1993, now substituted by Royal Decree 231/2008 of 15 February. The Spanish Government was entitled to issue the latter by Law 44/2006, of 29 December. Other relevant rules are Arts. 57 and 58 of Legislative Royal Decree 1/2007 of 16 November, approving a text refunding the General Law on the Defence of Consumers and Users and other supplementary laws, as well as Law 60/2003, of 23 December, on arbitration.
The consumer arbitration system only applies to consumer matters and disputes between professionals or businesses and consumers setting aside those cases dealing with intoxication, injury, or death or that show reasonable indications of a criminal offence. ${ }^{85}$ Consumer Arbitration Boards, the Commission of Consumer Arbitration Boards, the General Council, and arbitration tribunals are the bodies of the system. The main body are consumer arbitration boards which are in charge of managing the system and providing administrative and technical services to arbitrators and parties to arbitration. In addition to the National Consumer Arbitration Board, local boards can be established depending on the relevant public administration. Only consumers are entitled to request for arbitration before any consumer arbitration board agreed between the parties to arbitration; in default, the local board corresponding to the consumer's domicile is the one competent to administer the arbitration. ${ }^{86}$ Should a request (not) be admitted to arbitration, the decision can be challenged before the Commission of Consumer Arbitration Boards. ${ }^{87}$ The Commission is also in charge of issuing guidelines and reports with a view to coordinating arbitrators and avoiding contradictions. Anyway, the principles of independence and impartiality govern arbitrators' actuations meaning that arbitrators are entitled not to apply the said guidelines as long as they explain their reasons. In general, arbitrators have to comply specific requirements and show qualifications as requested by the General Council. $^{88}$

Consumer arbitration proceeds on an equity basis unless the parties require it to be in law, ${ }^{89}$ is meant to have a length of 6 months maximum, ${ }^{90}$ and is free from costs. Access to arbitration proceeds on a voluntary basis, but acceptance can be provided in different moments depending on whether the party to arbitration is a business or a consumer, to the extent that businesses may join ex ante the system in order to arbitrate all or some disputes arising from their trade; ${ }^{91}$ in this case, consumers only need to file a request for arbitration. Of course, acceptance can be also provided on ad hoc basis, by an arbitration agreement included in the consumer con-

85. See Arts. 57(1) of Law 44/2006 and 2(2) of Royal Decree 231/2007.

86. In case of several consumer arbitration boards covering the same territory, the smallest one is deemed to be competent. Should a territorial limitation be included in the public adhesion to the system issued by the relevant business, the consumer arbitration board to which the business submits is the one competent unless it has submitted to several boards in which case the consumer has a choice. See Art 8 of Royal Decree 231/2008.

87. Ibid., Art. 11(1).

88. Compliance of requirements and qualifications is monitored by the president of the relevant consumer arbitration board. See ibid., Art. 17.

89. Should arbitration be in law, all arbitrators have to be law graduates. Otherwise, this requirement is only applicable to those arbitrators stemming from the public administration. Arbitrations tribunals can be made of one or three arbitrators; in this case one stems from the public administration while the other ones act on behalf of consumer associations and business organisations. See ibid., Art. 21

90. Ibid., Art. 49

91. Ibid., Arts. 25 and 26 
tract, independently subscribed or even by request of arbitration followed by other party's acceptance. ${ }^{92}$

The advantage of an ex ante adhesion to the system is that businesses are allowed to display a distinctive sign indicating that they have joined the consumer arbitration system. ${ }^{93}$ In a similar vein, a public registry of businesses entering into the system has been set up under the supervision of the Spanish Agency of Consumption, Food Security and Nutrition, in order to make this information available to any interested party. ${ }^{94}$ So, any consumer trading with one of these businesses may rely on the latter's availability to reach a prompt solution to any issue arising between both parties; thereby businesses' reputation is enhanced by this means. In general, the system has been a success. But there is one significant issue though and concerns its voluntary character, i.e. it is up to businesses to join the system and although adhesion figures are very high, the same applies to businesses abandoning the system. ${ }^{95}$

\subsection{Collective Actions}

While Spain was one of the first countries in the European Union in addressing collective actions, the first rules dealing with them dating back to mid-1980s, ${ }^{96}$ Directive 98/27/EC on injunctions for the protection of consumers' interests, now replaced by Directive 2009/22/EC, ${ }^{97}$ made them more visible. However, Spanish rules on collective actions have been issued not systematically but on a piecemeal basis to the extent that almost each consumer directive laid down a rule on collective action and so each Spanish law transposing them did. ${ }^{98}$ The LEC also addresses collective actions, but it has not finishes fragmentation. As a matter of fact, there is fragmentation even within the LEC where several provisions scattered across the act deal with only some issues of collective proceedings. Against this background, only some collective cases have made their way to courts in the last 30 years, mostly injunctive actions; despite having been legally addressed in Spain, redress collective actions are rare in practice due to their costs

92. Ibid., Art. 24.

93. Ibid., Art. 28.

94. Ibid., Art. 33. The registry is supposed to be available online, but they are still working on it. See Agency of Consumption, Food Security and Nutrition <http://arbitrajedeconsumo.mspsi.es/avisoBuscadorEmpresas. html>.

95. Unfortunately current data are not available at the webpage of the Spanish Agency of Consumption, Food Security and Nutrition. Last data available at <http://consumo-inc.gob.es/arbitraje/memoria.htm> go back to 2007, when there were 61,759 consumer arbitrations. Noteworthy is that consumer arbitration is mostly resorted to in telecommunications, education, and energy matters, while other sectors do not take advantage of it mainly due to the lack of businesses' cooperation.

96. The already mentioned Law 26/1984 on the protection of consumers and users laid down the embryo of collective actions, as Art. 7 LOPJ did.

97. Directive 2009/22/EC of the European Parliament and of the Council of 23 April 2009 on injunctions for the protection of consumers' interests replacing the Directive 1998/27/EC, OJ 2009 L 110/51.

98. See M. Carballo Fidalgo, La protección del consumidor frente a las cláusulas no negociadas individualmente. Disciplina legal y tratamiento jurisprudencial de las cláusulas abusivas (2013) at 243; L. Carballo Piñeiro, 'La tipicidad de las acciones colectivas en el ordenamiento jurídico español', Justicia. Revista de derecho procesal 63 (2007). and difficulties first in legally understanding what is necessary to proceed and second in gathering group members, evidence, and administering enforcement in case the action is successful. ${ }^{99}$

Standing is a key issue and each Spanish consumer law laying down some sort of collective action deals with it, e.g. it makes injunctive and/or redress collective actions available to claim for the rights therein enshrined specifically establishing who has standing to bring them before court, usually some legal entities such as the Public Ministry or those state institutions in charge of protecting consumers, as well as consumer associations and business organisations. Nothing else is said about the procedure. Further specifications have to be found in the LEC which also has rule on standing. Pursuant to Article 11 LEC, only state entities and consumer associations are entitled to bring injunctive actions (i.e. those claiming general or diffuse interests) before courts, while in addition to those entities and associations, groups may also commence redress collective actions. However, the latter is far from usual and the rule is that consumer associations take the lead in conducting any kind of collective action. In view of the role these associations play in practice, they are granted legal aid, ${ }^{100}$ but it does not cover all costs, e.g. of gathering group members and informing them about the action. Notice to group members depends on the type of the collective action and varies from the court clerk informing of the action via mass media to the representative claimant being obliged to locate the group and inform each member of its intention to undertake the collective action even before bringing it to court. ${ }^{101}$ The latter is difficult and expensive, but the claimant may get court help to determine the group. ${ }^{102}$ Further uncertainties arise from the fact that the LEC simply indicates what happens if group members join the action during the proceeding, but says nothing about their right to opt in or to opt out. ${ }^{103}$ Accordingly, it is unclear who is bound by the final judgment although the LEC does acknowledge at least the ultra partes effect of this type of actions. ${ }^{104}$ In the same vein, LEC does not lay down a certification

99. The very first issue was already conceptualising collective and group interests. See L Bujosa Vadell, La protección jurisdiccional de los intereses de grupo (1995); P. Gutiérrez de Cabiedes e Hidalgo de Cabiedes, La tutela jurisdiccional de los intereses supraindividuales:colectivos y difusos (1999).

100. See Art. 37(d) of Real Decreto Legislativo 1/2007, de 16 de noviembre, por el que se aprueba el texto refundido de la Ley General para la Defensa de los Consumidores y Usuarios y otras leyes complementarias.

101. See Art. 15 LEC. There is no notice though in case of injunctive actions.

102. Ibid., Art. 256(1)(6). However, this provision has been strictly interpreted in order to balance the right to get information about the group from the respondent and the right to data protection to which the latter is obliged. See the Constitutional Court's judgement 96/2012 of 7 May.

103. Although the general interpretation is that it must be an opt-out system. See L. Carballo Piñeiro, Las acciones colectivas y su eficacia extraterritorial. Problemas de recepción y trasplante de las class actions en Europa (2009) 53

104. See Art. 222(3) LEC. Art. 221 LEC also addresses this issue but only in the event that the representative claimant is a consumer association. As this is the usual case, this provision is the key one when it comes to the binding effect of collective proceedings. 
phase or address judicial settlements in collective actions for which reason they are not feasible. ${ }^{105}$

All these issues make it difficult the commencement of collective actions. But the economic downturn has made them more interesting and an increase in their practice can be traced. ${ }^{106} \mathrm{~A}$ good example is the judgment No. 213/2013, of 9 May 2013, by which the Supreme Court ruled that stipulating a minimum interest rate - i.e. should indicators go down that rate, the mortgagor still has to pay the minimum contractually agreed in mortgage contracts - are null and void due to their unfair nature. However, account should be given of the existence of a request for a preliminary ruling before the CJEU stemming from a collective action brought in 2010 before a commercial court in Madrid by a consumer association and involving 101 banks for using those terms $;{ }^{107}$ in view of the length of the procedure, many consumers decided to individually claim, but the defendants have been applying for a stay on the grounds that the judgment to be rendered in the collective action is a preliminary issue in relation to those individual claims. ${ }^{108}$ Against this background, a commercial court in Barcelona decided to ask the CJEU whether such a rule is consistent with EU consumer protection arguing that 'the consumer is bound by the decision in those [collective] proceedings without having had the opportunity to put forward the appropriate pleas or adduce evidence with full equality of arms' ${ }^{109}$ In other words, the inconsistencies and gaps of the Spanish legislation as well as the length of procedures seem to be hampering access to justice and putting into question the role of collective actions in a democratic society.

\section{Final Remarks}

The economic downturn has struck the Spanish judiciary on both the supply and the demand sides of justice services, to the extent that it has undergone a severe budget restriction and had to confront the huge social conflict arising from it. Further austerity measures have deepened social conflict by hampering access to justice while first establishing high court fees and second severely curtailing legal aid's budget. Furthermore, the Spanish legal system was not ready to provide support to debtor natural persons in difficulties, and the judiciary has been made responsible for being just the mouth that pronounces the words of law. Alternatives to the traditional way of handling cases have been put in motion, but they do not seem to go beyond dealing with a few cases (and maybe it is not necessary to go further). Without questioning the need of a holistic approach to the justice system, the role of judge-made justice in a democratic society has to be vindicated, and if one conclusion can be drawn from the financial crisis is that the disregarding of such a role can be dangerous and fatal for social cohesion.

105. See L. Carballo Piñeiro, above n. 103, at 211-22. Seeking for alternatives see F. Gascón Inchausti, Tutela judicial de los consumidores y transacciones colectivas (2010).

106. The rise on collective actions also involve foreign companies as evidenced by cases Costa Cruceros (Juzgado de lo Mercantil No. 1, Madrid, 23 October 2012) and Ryanair (Juzgado de lo Mercantil No. 5, Madrid, 30 September 2013; Tribunal Superior de Justicia Madrid 765/2013, 30 October 2013), both discussed in L. Carballo Piñeiro, 'La construcción del mercado interior y el recurso colectivo de consumidores', in F. Esteban de la Rosa (ed.), La protección del consumidor en dos espacios de integración: Europa y América. Una perspectiva de Derecho internacional, europeo y comparado (2015), at 1055-1088.

107. The collective action is being handled by the Juzgado de lo Mercantil No. 11, Madrid, juicio verbal No. 471/2010, involving 15,000 consumers represented by the consumer association ADICAE, although the key issue for such a delay lies in the 101 defendants.

108. The European Central Bank has set the interest rate at which it lends money to commercial banks very low, but Spanish mortgagors are not taking advantage of it due to the so-called floor clauses, the abovementioned minimum interest rates included by banks in mortgage contracts. That is the reason why many consumers do not want to wait for the judgment in the collective action, because they have to comply with the actual terms of the contract, including those whose nullity is being requested. To make the situation even more complicated, the abovementioned Supreme Court's judgment of 2013 ruled out that those terms were null and void but argued that such a declaration only had ex nunc effects, i.e. terms must be removed from contracts, but banks do not have to give back the money already collected on their account. The Supreme Court changed this doctrine in its judgment No. $139 / 2015$ of 9 March and clarified that banks do have to give back the money already collected but only from the 9 May 2013.

109. See Request for a preliminary ruling from the Juzgado de lo Mercantil No. 9, Barcelona (Spain) lodged on 11 August 2014, Jorge Sales Sinués v. Caixabank, S.A. (Case C-381/14). 